\title{
Propylthiouracil-induced congenital hypothyroidism upregulates vimentin phosphorylation and depletes antioxidant defenses in immature rat testis
}

\author{
Ariane Zamoner, Kátia Padilha Barreto ${ }^{1}$, Danilo Wilhelm Filho², Fabíola Sell ${ }^{2}$, Viviane \\ Mara Woehl ${ }^{3}$, Fátima Costa Rodrigues Guma, Regina Pessoa-Pureur and Fátima Regina \\ Mena Barreto Silva ${ }^{4}$
}

Departamento de Bioquímica, Instituto de Ciências Básicas da Saúde, UFRGS, Porto Alegre, CEP 90035-003, RS, Brazil

${ }^{1}$ Departamento de Farmacologia e Fisiologia, Centro de Ciências da Saúde, Universidade Federal de Santa Maria, Santa Maria, CEP 97105-900, RS, Brazil

${ }^{2}$ Departamento de Ecologia e Zoologia, ${ }^{3}$ Departamento Ciências Morfológicas e and ${ }^{4}$ Departamento de Bioquímica, Centro de Ciências Biológicas, Universidade Federal de Santa Catarina, Florianópolis, CEP 88040-970, SC, Brazil

(Correspondence should be addressed to F R M B Silva who is now at Departamento de Bioquímica, Centro de Ciências Biológicas, UFSC, Campus Universitário, Bairro Trindade, Cx Postal 5069, CEP: 88040-970 Florianópolis, Santa Catarina, Brazil; Email: mena@mbox1.ufsc.br)

\begin{abstract}
Congenital hypothyroidism was induced in rats by adding 0.05\% 6-propyl-2-thiouracil in the drinking water from day 9 of gestation, and continually up to postnatal day 15. Structural alterations observed by light microscopy of seminiferous tubules and by transmission electron microscopy of Sertoli cells of treated animals were consistent with hypothyroid condition. Hypothyroidism was also associated with high phospho-p38 mitogen-activated protein kinase and decreased phospho-extracellular signal-regulated kinase $1 / 2$ levels. Furthermore, the phosphorylation and the immunoreactivity of cytoskeletal-associated vimentin were increased without altering vimentin expression, suggesting an accumulation of insoluble and phosphorylated vimentin. These alterations in intermediate filament dynamics could result in loss of Sertoli cell cytoskeletal integrity and be somewhat related to the deleterious effects of hypothyroidism in testis. In addition, the mitochondrial alterations observed could also be related to defective cytoskeletal dynamics implying in cell damage. Moreover, we observed decreased oxygen consumption and unaltered lipid peroxidation in hypothyroid testis. However, we demonstrated decreased enzymatic and non-enzymatic antioxidant defenses, supporting an increased mitochondrial reactive oxygen species (ROS) generation, contributing to biochemical changes in hypothyroid testis. In addition, the changes in the testis histoarchitecture could be ascribed to cytoskeletal alterations, decreased antioxidant defenses, and increased ROS generation, leading to oxidative stress in the organ.
\end{abstract}

Journal of Molecular Endocrinology (2008) 40, 125-135

\section{Introduction}

The Sertoli cells are the principal structural elements of the seminiferous epithelium, providing physical support and an environment conducive to germ cell development and maturation (Holsberger \& Cooke 2005). These cells play a pivotal role in the regulation and maintenance of spermatogenesis and are the site of action of all hormonal influences modulating testis development. They also provide physical support to germ cells, form the blood-testis barrier, and secrete protein products thought to be essential to the maintenance and control of spermatogenesis (Maran et al. 1999). The hormonal factors controlling the duration of Sertoli cell proliferation are critical determinants of fertility (Jannini et al. 1995, Holsberger \& Cooke 2005).

Thyroid hormones (THs) are essential for normal postnatal growth and development, and are known to play a fundamental role in the regulation of the energy metabolism of almost all mammalian tissues. TH receptors are highly expressed in neonatal Sertoli cells, indicating that the developing Sertoli cells and testis may be important TH targets (Jannini et al. 1999, Rao et al. 2003). In this context, Jannini et al. (1995) and Holsberger et al. (2005) provided strong evidence that THs regulate Sertoli cell proliferation and differentiation in the neonatal testis. Accordingly, alterations in thyroid activity are frequently associated with changes in male reproductive functions, since hypothyroidism is associated with a marked delay in sexual maturation and development (Holsberger \& Cooke 2005). However, the complete mechanisms by which THs are able to control Sertoli cell and testicular development is still uncertain.

Intermediate filaments (IFs) are cytoskeletal polymers that provide crucial structural support in the nucleus and cytoplasm of eukaryotic cells. Perturbation of their function and dynamics accounts for fragile cells

DOI: 10.1677/JME-07-0089 Online version via http://www.endocrinology-journals.org 
that cannot sustain mechanical and non-mechanical stress. In addition, the IFs are able to modulate cellular responses to metabolic stress, programmed cell death, cell migration, and even tissue growth (Coulombe \& Wong 2004). Vimentin is an IF protein often expressed transiently during development (Menet et al. 2001) that has been described in Sertoli cells during fetal and postnatal periods (Romeo et al. 1995, Show et al. 2003, Franke et al. 2004), where it plays important roles in the modifications of Sertoli cell morphology, junctional processes, structural integrity, and cytoplasmic organization that occur during spermatogenesis (Russell \& Peterson 1985, Tanemura et al. 1994, Show et al. 2003, He et al. 2007).

Phosphorylation modulates both reciprocal interactions of IF proteins with other cytoskeletal components and the continuous exchange of IF subunits between a soluble pool and the polymerized IF (Inagaki et al. 1987, Chou et al. 1996, Inada et al. 1999, Zamoner et al. 2005, 2006, 2007). In this context, the mitogen-activated protein kinase (MAPK) family have been described to phosphorylate IF proteins (Brownlees et al. 2000) and participate in cell cycle arrest and inhibition of cell proliferation, a hallmark of hypothyroidism (Moro et al. 2004, Franco et al. 2006). We have recently described that THs are able to modulate the in vivo and in vitro IF phosphorylation and expression in rat testis and cerebral cortex through genomic and non-genomic mechanisms (Zamoner et al. 2005, 2006, 2007). Furthermore, we have also demonstrated that vimentin hyperphosphorylation was associated with MAPK activation and oxidative stress in testis from hyperthyroid rats (Zamoner et al. 2007).

The THs are largely described as important modulators of cellular metabolism. Several studies demonstrated that hyperthyroid tissues exhibit increased reactive oxygen species (ROS) generation (Venditti \& Di Meo 2006). The generation of ROS in vivo is a constant phenomenon due to either physiological metabolism or pathological alterations, and therefore oxidative stress consists one of the major threat to cell homeostasis in aerobic organisms (Gaté et al. 1999). In the male reproductive system, the testis, epididymis, sperm, and seminal plasma contain high activities of antioxidant enzymes that protect sperm against ROS deleterious effects (Zini \& Schlegel 1996, $1997 a, b$, Potts et al. 2000). However, the effect of congenital hypothyroidism in oxidative stress and antioxidant defenses is still unclear.

In an attempt to better understand some mechanisms underlying the testicular alterations observed in hypothyroidism, we investigated the effects of 6-propyl-2-thiouracil (PTU)-induced congenital hypothyroidism on testicular morphology, somatic indices, involvement of MAPK cascade, vimentin expression and phosphorylation, and some aspects of oxidative stress in young rats in the present study.

\section{Materials and methods}

\section{Chemicals}

$\left[{ }^{32} \mathrm{P}\right] \mathrm{Na}_{2} \mathrm{HPO}_{4}$ was purchased from CNEN (São Paulo, Brazil). Benzamidine, leupeptin, antipain, pepstatin, chymostatin, anti-vimentin antibody (clone vim 13.2), peroxidase-conjugated rabbit anti-mouse immunoglobulin G (IgG), monoclonal anti- $\beta$-actin antibody, acrylamide, and bis-acrylamide were obtained from Sigma Chemical Co. Anti-p44/42 MAP kinase (antiextracellular signal-regulated kinases $1 / 2($ ERK1/2)), anti-phospho-p44/42 MAP kinase (anti-phospho ERK1/2), anti-p38 MAPK, anti-phospho p38 MAPK, anti-stress-activated protein kinase (SAPK)/Jun N-terminal kinases (JNK), or anti-phospho SAPK/JNK, antibodies were from Cell Signaling Technology Inc. (Danver, MA, USA). The chemiluminescence ECL kit and rat thyroid-stimulating hormone (rTSH) kit were obtained from Amersham Bioscience. TRIzol reagent and SuperScript II RT are from Invitrogen and Taq DNA Polymerase from CENBIOT (Porto Alegre, RS, Brazil).

\section{Animals}

Fifteen-day-old male Wistar rats used in this study were originated from litters in our rat colony. The rats were maintained under a $12 \mathrm{~h}$ light: $12 \mathrm{~h}$ darkness cycle in constant temperature $\left(22^{\circ} \mathrm{C}\right)$ room. On the day of birth, the litter size was culled to eight pups. Litters smaller than eight pups were not included in the experiments. Water and $20 \%(\mathrm{w} / \mathrm{w})$ protein commercial chow were available ad libitum. All the animals were carefully monitored and maintained in accordance with ethical recommendations of the Brazilian Veterinary Medicine Council and the Brazilian College of Animal Experimentation.

\section{Induction of hypothyroidism}

Wistar rats were mated and the day of appearance of the vaginal plug was considered day 0 of fetal age. Congenital hypothyroidism was induced by adding $0.05 \%$ PTU in the drinking water from day 9 of gestation, and continually up to postnatal day 15 . Euthyroid rats, receiving only water during the same period, were used as controls. The dosage of PTU used is in agreement with previous reports (Choudhury et al. 2003, Dong et al. 2005, Gravina et al. 2007). Control and hypothyroid animals were used when 15 days old, considering that we have previously demonstrated the in vivo (Zamoner et al. 2007) and in vitro (Zamoner et al. 2005) cytoskeleton susceptibility to $3,5,3^{\prime}$-triiodo-L-thyronine $\left(\mathrm{T}_{3}\right)$ in 15-day-old rat testis. In all animal groups, the testes weight was measured on the day of the experiment. 


\section{Determination of hormone levels}

Blood was collected, separated by centrifugation $(500 \mathrm{~g}, 10 \mathrm{~min})$ and the serum was stored at $-20^{\circ} \mathrm{C}$. Twelve to fifteen samples of control and treated groups were used to measure the serum hormone levels. Serum levels of $T_{3}$ and thyroxine $\left(T_{4}\right)$, total and free, and TSH (ultrasensitivity method) were determined by RIA. The hTSH assay sensitivity was $0.003 \mu \mathrm{U} / \mathrm{ml}$ (CRIESP, São Paulo, Brazil). In order to better characterize the hypothyroidism, the TSH levels were also measured by rTSH kit - Biotrak Assay System. The rTSH assay sensitivity was $0.05 \mathrm{ng} /$ tube. The crossreactivity with rat TSH is $100 \%$ and the non-specific binding was determined to be $<5 \%$. The assay procedures were run according to the manufacturer's specifications.

\section{Light and transmission electron microscopy}

For light microscopy, the testes were removed, fixed in Bouin's solution overnight, and subsequently transferred to $70 \%$ ethanol for storage. The specimens were then dehydrated in a graded series of ethanol and embedded in Paraplast Plus. They were sectioned in $5 \mu \mathrm{m}$ slices, stained with hematoxylin and eosin, and examined by light microscopy.

For transmission electron microscopy, the contralateral testes were fixed with $3 \%$ glutaraldehyde, buffered with $0.2 \mathrm{M}$ phosphate buffer $(\mathrm{pH} 7 \cdot 4)$, and post-fixed with $1 \%$ osmium tetroxide in the same buffer. They were dehydrated in a crescent concentration series of ethanol and passage through propylene oxide. The specimens were embedded with Spurr. Thin sections were obtained with glass knives in a Porter Blum MT-2 ultramicrotome, stained with uranyl acetate and lead citrate (Watson 1958, Reynolds 1963), and observed with a JEM-1200Ex transmission electron microscope.

\section{In vitro ${ }^{32} \mathrm{P}$ incorporation into vimentin}

The in vitro phosphorylation of vimentin was carried out as described previously by Funchal $e t$ al. (2003) and Zamoner et al. (2005). In brief, testes of 15-day-old rats were pre-incubated at $30^{\circ} \mathrm{C}$ for $20 \mathrm{~min}$ in a KrebsHEPES medium containing $124 \mathrm{mM} \mathrm{NaCl}, 4 \mathrm{mM} \mathrm{KCl}$, $1.2 \mathrm{mM} \mathrm{MgSO}_{4}, 25 \mathrm{mM}$ Na-HEPES ( $\mathrm{pH} \mathrm{7.4),} 12 \mathrm{mM}$ glucose, $1 \mathrm{mM} \mathrm{CaCl}_{2}$, and the following protease inhibitors: $1 \mathrm{mM}$ benzamidine, $0 \cdot 1 \mu \mathrm{M}$ leupeptin, $0.7 \mu \mathrm{M}$ antipain, $0.7 \mu \mathrm{M}$ pepstatin, and $0.7 \mu \mathrm{M}$ chymostatin. Incubation was carried out with $100 \mu \mathrm{l}$ of the basic medium described above, containing $80 \mu \mathrm{Ci}\left[{ }^{32} \mathrm{P}\right]$ orthophosphate. The labeling reaction was allowed to proceed for $30 \mathrm{~min}$ at $30^{\circ} \mathrm{C}$ and then stopped with $1 \mathrm{ml}$ of cold stop buffer containing $150 \mathrm{mM} \mathrm{NaF}, 5 \mathrm{mM}$
EDTA, 5 mM EGTA, $50 \mathrm{mM}$ Tris-HCl (pH 6.5), and the protease inhibitors described above. Testes were then washed twice by decanting with the stop buffer to remove excess radioactivity. After the in vitro phosphorylation procedures, the IF-enriched cytoskeletal fraction was extracted as described below.

\section{Extraction of IF-enriched cytoskeletal fraction}

The extraction of IF-enriched cytoskeletal fraction was proceeded as described by Funchal et al. (2003). Briefly, testes were homogenized in $600 \mu \mathrm{l}$ ice-cold buffer containing $5 \mathrm{mM} \mathrm{KH}_{2} \mathrm{PO}_{4}, 600 \mathrm{mM} \mathrm{KCl}, 10 \mathrm{mM}$ $\mathrm{MgCl}_{2}, 2 \mathrm{mM}$ EGTA, $1 \mathrm{mM}$ EDTA, $1 \%$ Triton X-100, and the protease inhibitors described above. The homogenate was centrifuged at $15800 \mathrm{~g}$ for $10 \mathrm{~min}$ at $4{ }^{\circ} \mathrm{C}$ in an Eppendorf centrifuge. The insoluble material was resuspended in $600 \mu \mathrm{l}$ of the same buffer and centrifuged as described. The pellet constituted the high-salt Triton-insoluble IF-enriched cytoskeletal fraction. This pellet was then dissolved in $1 \%$ SDS. Some experiments used total protein homogenate of the testis. For this, the tissue was homogenized in $300 \mu \mathrm{l}$ of a lysis solution (2 mM EDTA, $50 \mathrm{mM}$ Tris$\mathrm{HCl}(\mathrm{pH} 6 \cdot 8), 4 \%$ SDS). The protein content was measured by the method of Lowry et al. (1951). For SDS-PAGE analysis, samples were dissolved in $25 \%$ (v/v) of a solution containing 40\% glycerol, $5 \%$ mercaptoethanol, $50 \mathrm{mM}$ Tris- $\mathrm{HCl}$ (pH 6.8), and boiled for $3 \mathrm{~min}$. Equal protein concentrations of the total protein homogenate or the IF-enriched cytoskeletal fraction were analyzed by 10\% SDS-PAGE (Laemmli 1970) and transferred to nitrocellulose membranes for $1 \mathrm{~h}$ at $15 \mathrm{~V}$ in transfer buffer $(48 \mathrm{mM}$ Trizma, $39 \mathrm{mM}$ glycine, $20 \%$ methanol, and $0.25 \%$ SDS). In the experiments on in vitro ${ }^{32} \mathrm{P}$ incorporation, the nitrocellulose membranes containing the IFenriched cytoskeletal fraction were exposed to X-ray films (T-mat G/RA) at $-70{ }^{\circ} \mathrm{C}$ with intensifying screens, and finally the autoradiograms were obtained and quantified as described below.

\section{Western blot analysis}

The nitrocellulose membranes were washed for $10 \mathrm{~min}$ in Tris-buffered saline (TBS; $0.5 \mathrm{M} \mathrm{NaCl}, 20 \mathrm{mM}$ Trizma $(\mathrm{pH} 7 \cdot 5)$ ), followed by 2-h incubation in blocking solution (TBS plus 5\% defatted dried milk (MTBS)). After incubation, the blot was washed twice for $5 \mathrm{~min}$ with TBS plus $0.05 \%$ Tween 20 (T-TBS), and then incubated overnight at $4{ }^{\circ} \mathrm{C}$ in blocking solution containing the monoclonal anti-vimentin antibody (clone vim 13.2), and diluted 1:400. In experiments designated to study the MAPK cascade anti-ERK1/2, antiphospho ERK1/2, anti-p38 MAPK, anti-phospho p38 
MAPK, anti-SAPK/JNK, or anti-phospho SAPK/JNK, antibodies were diluted 1:2000. The monoclonal anti- $\beta$ actin was diluted 1:1000 in blocking solution. The blots were then washed twice for $5 \mathrm{~min}$ with T-TBS and incubated for $2 \mathrm{~h}$ in MTBS containing peroxidaseconjugated rabbit anti-mouse IgG diluted 1:4000 (for anti-vimentin and anti-actin) or anti-rabbit IgG 1:1000 (for MAPK cascades). The blots were washed twice again for $5 \mathrm{~min}$ with T-TBS and twice for $5 \mathrm{~min}$ with TBS. The blots were then developed using a chemiluminescence ECL kit. Autoradiograms and immunoblots were quantified by scanning the films with a Hewlett-Packard ScanJet 6100C scanner and determining optical densities with an OptiQuant version 02.00 software (Packard Instrument Company, Canberra, Australia).

\section{Reverse transcription PCR (RT-PCR)}

Total RNA from testes cells was isolated using TRIzol reagent. CDNA was synthesized from $1 \mu \mathrm{g}$ total RNA. RNA was primed with $0.5 \mu \mathrm{g}$ oligo $(\mathrm{dT})_{12-18}$ primer (reaction volume $20 \mu \mathrm{l}$ ). After the RNA was denatured $\left(10 \mathrm{~min}\right.$ at $\left.70^{\circ} \mathrm{C}\right)$ and cooled on ice, the following reagents were mixed and then added: $10 \mathrm{mM}$ of each deoxynucleoside triphosphate $(\mathrm{dNTP}), 6 \mu \mathrm{l} 5 \times$ reverse transcription (RT) buffer, $0 \cdot 1 \mathrm{mM}$ dithiothreitol, and $200 \mathrm{U}$ SuperScript RT (reaction volume $30 \mu \mathrm{l}$ ). Reaction was performed by incubation for $1 \mathrm{~h}$ at $42{ }^{\circ} \mathrm{C}$. Amplification reactions consisted of $0 \cdot 2 \mu \mathrm{M}$ primer (described in Table 1), $10 \mu \mathrm{M}$ of each dNTP, PCR buffer, $5 \mu$ of the cDNA reaction, $0.5 \mathrm{U}$ Taq DNA polymerase. Amplification was carried out during 30 PCR cycles, each cycle consisting of a denaturation step at $94{ }^{\circ} \mathrm{C}$ for $1 \mathrm{~min}$, an annealing step at $60^{\circ} \mathrm{C}$ for $2 \mathrm{~min}$, and an extension step at $74^{\circ} \mathrm{C}$ for 3 min after the last cycle, and finally, incubation for another $7 \mathrm{~min}$ at $74^{\circ} \mathrm{C}$ was performed. The PCR products $(5 \mu \mathrm{l})$ were analyzed on agarose gel containing $0.5 \mu \mathrm{g} / \mathrm{ml}$ ethidium bromide (Guma et al. 2001).

Oligonucleotides of $5^{\prime}$ primers and $3^{\prime}$ primers of target genes.

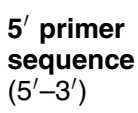

\section{mRNA \\ species}

Vimentin

GCCTATGT-

GACCCGGT CCTCGGCAGT- CATTGTCAA GCGCCT

$\beta$-Actin

\section{$3^{\prime}$ primer sequence $\left(5^{\prime}-3^{\prime}\right)$}

Size of PCR product (bp)
Table 1 Effect of congenital hypothyroidism on serum levels of thyroid hormones and thyroid-stimulating hormone (TSH) in rats

\begin{tabular}{|c|c|c|}
\hline & Control & Hypothyroid \\
\hline $\mathrm{FT}_{3}(\mathrm{ng} / \mathrm{ml})$ & $3.25 \pm 0.01$ & $0.35 \pm 0.003^{\dagger}$ \\
\hline $\mathrm{FT}_{4}(\mathrm{ng} / \mathrm{dl})$ & $2 \cdot 21 \pm 0.003$ & $0.30 \pm 0.002^{\dagger}$ \\
\hline $\mathrm{T}_{3}(\mathrm{ng} / \mathrm{ml})$ & $9.39 \pm 0.01$ & $0.72 \pm 0.003^{\dagger}$ \\
\hline $\mathrm{T}_{4}(\mu \mathrm{g} / \mathrm{dl})$ & $6.11 \pm 0.001$ & $0.80 \pm 0.001^{\dagger}$ \\
\hline $\begin{array}{l}\text { TSH }(\mu \mathrm{U} / \mathrm{ml})-\mathrm{hTSH} \\
\text { kit }\end{array}$ & $0.03 \pm 0.001$ & $0.46 \pm 0.002^{\dagger}$ \\
\hline $\begin{array}{l}\mathrm{TSH}(\mathrm{ng} / \mathrm{ml})-\mathrm{rTSH} \\
\text { kit }\end{array}$ & $0.93 \pm 0.03$ & $4 \cdot 13 \pm 0 \cdot 2^{*}$ \\
\hline $\begin{array}{l}\text { Serum levels of free and } \\
\text { (FT }_{4} \text { and } \mathrm{T}_{4} \text { respectively } \\
n=9 \text { from controls and } r \\
\text { rTSH, rat TSH. Statistica } \\
\text { determined by Student's }\end{array}$ & $t$-test, are indice & $\begin{array}{l}\text { ctively), free anc } \\
\text { orted as means } \\
\text { up. hTSH, hum } \\
\text { from controls, a } \\
0.0001,{ }^{\dagger} P<0 .\end{array}$ \\
\hline
\end{tabular}

\section{Oxygen consumption measurements}

Testis from controls and hypothyroid pups were carefully excised, surface dried with filter paper, weighted, and exhaustively washed in ice-cold isotonic KrebsRinger bicarbonate (KRb) solution containing $15 \mathrm{mM}$ glucose $(\mathrm{pH} 7 \cdot 4)$. Small slices $(50-80 \mathrm{mg})$ from these tissues were resuspended in $2 \mathrm{ml}$ of the $\mathrm{KRb}$ buffer settled in a Tucker chamber containing a Clark electrode, and rates of oxygen consumption were recorded on an oxygraph for $2 \mathrm{~min}$ at a controlled temperature $\left(25 \pm 1^{\circ} \mathrm{C}\right)$. The oxygen consumption was expressed as $\mu \mathrm{mol} \mathrm{O}_{2} / \mathrm{min}$ per $\mathrm{g}$ and measured in triplicate (Estabrook 1984).

\section{Antioxidant enzyme assays}

Tissue was homogenized $(\sim 500 \mathrm{mg}$ tissue in nine volumes of buffer) in a buffer containing $0 \cdot 1 \%$ Triton $\mathrm{X}-100,0 \cdot 12 \mathrm{M} \mathrm{NaCl}, 30 \mathrm{mM} \mathrm{NaH} \mathrm{PO}_{4}(\mathrm{pH} 7 \cdot 4)$, and also containing freshly prepared protease inhibitors $(0.3 \mathrm{mM}$ phenylmethylsulphonyl fluoride and $0.05 \mathrm{mM}$ trypsin inhibitor). The use of Triton is essential for the measurement of total antioxidant enzymatic capacity of the tissue. Homogenization was carried out at $4{ }^{\circ} \mathrm{C}$, using 15 strokes in a Potter-Elvehjem homogenizer, followed by centrifugation at $1000 \mathrm{~g}$ for $5 \mathrm{~min}$ at $4{ }^{\circ} \mathrm{C}$. The supernatants were used for enzymatic evaluations and TBARS contents. Aliquots of the extracts were stored in liquid nitrogen $\left(-170{ }^{\circ} \mathrm{C}\right)$ and examined separately for each enzyme. Superoxide dismutase (SOD) activity was measured according to the method of cytochrome $c$ reduction (Flohé \& Gunzler 1984). Catalase (CAT) activity was determined by the decrease in hydrogen peroxide (10 $\mathrm{mM}$ solution) concentration at $240 \mathrm{~nm}$ (Aebi 1984). Glutathione peroxidase (GPx) was measured through the system glutathione/ 
$\mathrm{NADPH} /$ glutathione reductase by the dismutation of tert-butylhydroperoxide (Flohé \& Gunzler 1984). Glutathione reductase (GR) was measured through the oxidation rate of $\mathrm{NADPH}$, in a reaction medium containing $0 \cdot 1 \mathrm{M} \mathrm{NaH}_{2} \mathrm{PO}_{4}$ buffer $(\mathrm{pH} 7 \cdot 0$ ) containing $0 \cdot 1 \%$ DPTA and $1.0 \mathrm{mM}$ oxidized glutathione (GSSG) (Carlberg \& Mannervik 1985). The enzyme glutathione $S$ transferase (GST) was evaluated according to Habig et al. (1974), using CDNB as a substrate.

\section{Glutathione assay}

GSH was measured according to Beutler (1975), using Elmann's reagent (DTNB). Tissue acid extracts were obtained immediately after tissue excision by the addition of $12 \%$ trichloroacetic acid $(1: 4 \mathrm{v} / \mathrm{v})$, and then centrifuged. Fresh supernatants from the acid extracts were added to $0.25 \mathrm{mM}$ DTNB in $0.1 \mathrm{M}$ $\mathrm{NaH}_{2} \mathrm{PO}_{4}(\mathrm{pH} 8.0)$, and the formation of thiolate anion was determined at $412 \mathrm{~nm}$. TG was measured according to the method of Tietze (1969), and GSSG was calculated in equivalents of GSH $(1 \mathrm{GSSG}=2 \mathrm{GSH})$.

\section{Lipid peroxidation (TBARS)}

Determination of thiobarbituric acid-reactive substances (TBARS) was used to assay endogenous lipid oxidation according to Ohkawa et al. (1979) and Bird \& Draper (1984). Fresh homogenates were added to $0.2 \mathrm{mM}$ butylhydroxytoluene (BHT) to avoid further artifactual lipid oxidation. Tissue acid extracts were obtained by the addition of the homogenate to trichloroacetic acid $12 \%(1: 4 \mathrm{v} / \mathrm{v})$, and then centrifuged at $5000 \mathrm{~g}$ for $3 \mathrm{~min}$. Supernatants were added to $0.67 \%(\mathrm{w} / \mathrm{v})$ 2-thiobarbituric acid, maintained in boiling water for $60 \mathrm{~min}$, cooled at $5{ }^{\circ} \mathrm{C}$ for $30 \mathrm{~min}$, and then measured spectrophotometrically at $535 \mathrm{~nm}$ in triplicate. Absorbance was expressed as nmol TBARS/g tissue $\left(E_{535}=153 \mathrm{mM} / \mathrm{cm}\right)$. Frozen samples were not used because even when reacted with BHT, they showed artifactual lipid autoxidation and, therefore, enhanced TBARS levels (Wilhelm Filho et al. 2001).

\section{Statistical analysis}

Data were statistically analyzed by one-way ANOVA followed by the Tukey-Kramer multiple comparison tests when the $F$-test was significant or by Student's $t$-test. All analyses were performed using the GraphPad InStat Software (San Diego, CA, USA) version 1.12a.

\section{Results}

Hypothyroidism was induced by adding $0 \cdot 05 \%$ PTU in the drinking water from day 9 of gestation, and continually up to postnatal day 15 , resulting in decreased serum concentrations of free and total $\mathrm{FT}_{3}$, $\mathrm{T}_{3}$, and $\mathrm{FT}_{4}, \mathrm{~T}_{4}$, associated with a significant increase in the TSH serum levels (Table 1). Furthermore, we observed a decrease in body and testicular weights of hypothyroid rats (Table 2 ).

Light micrographs of testes sections from control and hypothyroid rats are shown in Fig. 1. The seminiferous tubules from control testes had the typical organization and the lumen was already formed (Fig. 1A), while in the hypothyroid rats the seminiferous tubules were disorganized, showing no lumen formation, when compared with control animals (Fig. 1B). Transmission electron microscopy of Sertoli cells from hypothyroid rats showed atypical Golgi apparatus presenting swollen and disorganized vesicles, as well as abundant secretion vesicles. Moreover, hypothyroid Sertoli cells showed swollen mitochondria with markedly dilated cristae compared with control cells (Fig. 1C and D).

In addition, the effect of hypothyroidism on the in vitro phosphorylation of the Triton-insoluble cytoskeletal-associated vimentin was evaluated. The results demonstrated that congenital hypothyroidism increased the in vitro phosphorylation of this protein (Fig. 2).

We also analyzed the immunocontent of vimentin both in the total tissue homogenate and in the cytoskeletal fraction. The results showed that the vimentin immunocontent in tissue homogenate was unaltered, whereas it was increased in the cytoskeletal fraction (insoluble pool) from hypothyroid rat testis (Fig. 3). Furthermore, RT-PCR analysis showed that vimentin expression was not altered in the testes of hypothyroid animals (Fig. 4).

We next investigated the effect of hypothyroidism on MAPK signaling pathways (ERK1/2, - SAPK/JNK and p38 MAPK). Results showed that in congenital hypothyroidism the expression of total and phosphoERK1/2 were diminished while total and phosphoSAPK/JNK were unaltered, nonetheless, despite the decrease in total p38 MAPK, phospho-p38 was increased (Fig. 5A-C).

Taking into account that THs are associated with hypermetabolic activity in several cell types (Venditti \& Di

Table 2 Effect of congenital hypothyroidism on body and testicular weight

\section{Body weight $(\mathrm{g}) \quad$ Testis weight $(\mathrm{mg})$}

$\begin{array}{lll}\text { Treatment } & & \\ \text { Control } & 23 \cdot 0 \pm 1 \cdot 5 & 51 \cdot 0 \pm 0 \cdot 9 \\ \text { Hypothyroid } & 15 \cdot 3 \pm 0 \cdot 33^{\star} & 29 \cdot 1 \pm 0 \cdot 3^{*}\end{array}$

Data are reported as means + S.E.M.; $n=12$ for control and hypothyroid groups. Statistically significant differences from controls, as determined by Student's $t$-test, are indicated. ${ }^{\star} P<0 \cdot 001$.

Journal of Molecular Endocrinology (2008) 40, 125-135 
Control

A

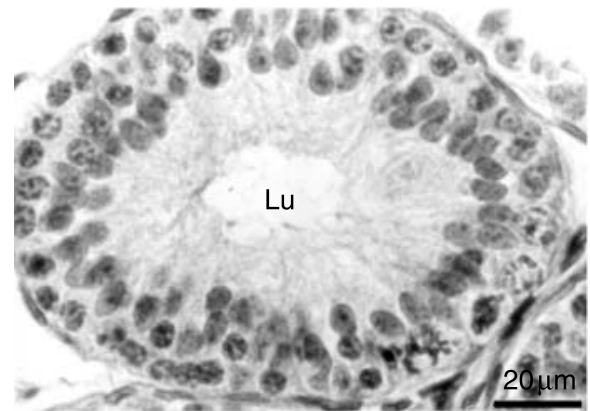

C

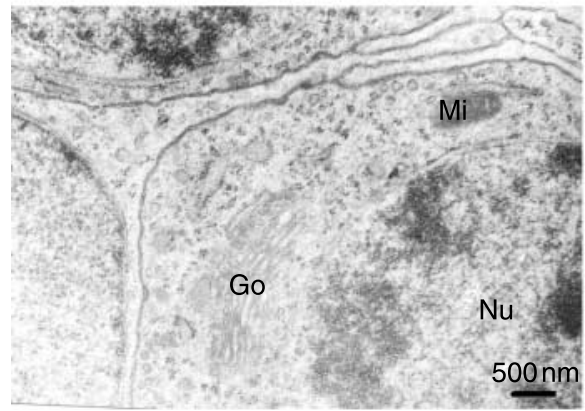

Hypothyroid

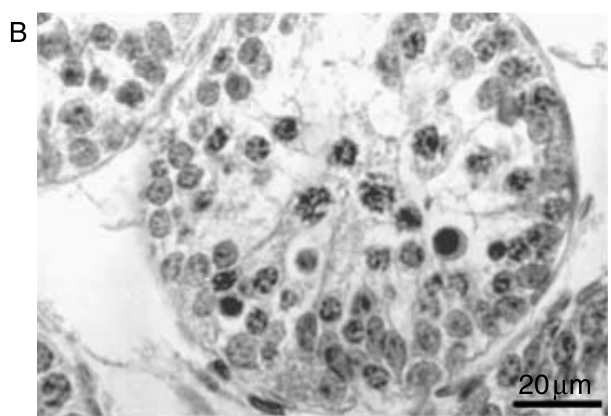

D

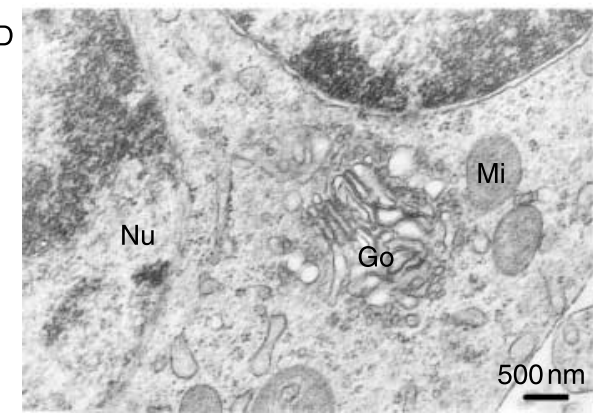

Figure 1 Light and transmission electron micrographs of control and hypothyroid rat testis. (A and B) Hematoxylin-eosin-stained sections of seminiferous tubules from control and hypothyroid rat testis.

(A) Seminiferous tubules showing lumen formation (Lu) and tubular integrity in control cells.

(B) Disorganized seminiferous tubules from hypothyroid rat testis without appearance of lumen. (C and D) Transmission electron micrograph of Sertoli cells. (D) shows disorganized Golgi apparatus (Go) with secretion vesicles and swollen mitochondria (Mi) with dilated cristae in Sertoli cell from hypothyroid rat testis compared with controls $(\mathrm{C})$. Nu, nucleus.

Meo 2006), we investigated some parameters of oxidative metabolism in congenital hypothyroid testis, such as oxygen consumption, lipid peroxidation, as well as the enzymatic and non-enzymatic antioxidant defenses. The results showed that oxygen consumption was diminished in hypothyroid testis, compared with the control group, a metabolic state compatible with the hypothyroid status

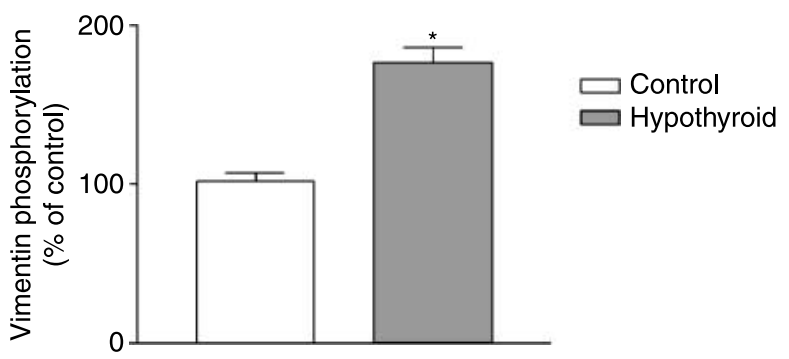

Figure 2 Effect of congenital hypothyroidism on vimentin phosphorylation in immature rat testis. Fifteen-day-old rat testes were incubated in the presence of ${ }^{32} \mathrm{P}$ orthophosphate for $30 \mathrm{~min}$. The high-salt Triton-insoluble cytoskeletal fraction0-0001. was extracted and the radioactivity incorporated into vimentin was measured. Data are reported as means \pm S.E.M. of 17 animals and expressed as percentage of control. Statistically significant difference from controls, as determined by Student's $t$-test, is indicated. ${ }^{*} P<0.0001$
(Fig. 6). In addition, TBARS levels were not altered, suggesting no modifications in lipid peroxidation associated with hypothyroidism in rat testes (Fig. 7). Moreover, we observed a decrease in total (TG) and reduced $(\mathrm{GSH})$ glutathione contents, while the levels of oxidized glutathione (GSSG) were unaltered. Furthermore, the activities of glutathione reductase (GR) and GST were significantly inhibited, without altering the GPx activity in hypothyroid group (Fig. 8). In addition, hypothyroid rat testis presented increased catalase (CAT; Fig. 9A) and decreased SOD activities (Fig. 9B), when compared with normal animals.

\section{Discussion}

In the present study, the effectiveness of PTU in inducing a hypothyroid condition was confirmed by the reduction of $\mathrm{T}_{3}$ ) and $\mathrm{T}_{4}$ serum levels with a marked increase in TSH secretion, as well as by the impairment of testicular growth and decreased body weight.

The light microscopy results showed a disorganization of the seminiferous tubules, indicating that PTU treatment provoked significant structural alterations in the germinative epithelium. In addition, the 


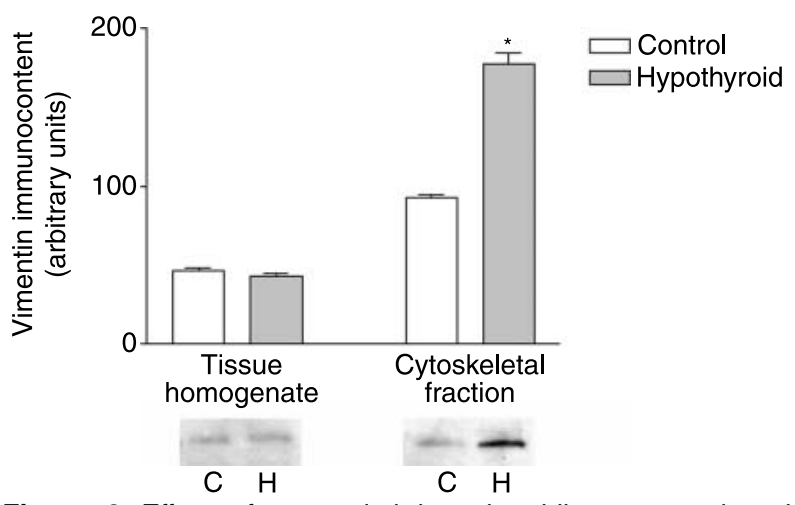

Figure 3 Effect of congenital hypothyroidism on total and cytoskeletal vimentin immunocontent of immature rat testis. The immunocontent of total (tissue homogenate) and high-salt Tritoninsoluble vimentin was measured. Representative immunoblots: C, control; H, hypothyroid. Scans from 15 different animals from each group were quantified. Results are expressed as mean \pm S.E.M. Statistical analysis: one-way ANOVA followed by TukeyKramer multiple comparison test. ${ }^{\star} P<0.0001$.

appearance of lumen, which marks the maturation of the Sertoli cells (Tindall et al. 1975, Russel et al. 1989), was observed only in the seminiferous tubules from control animals. Our results are in line with previous reports describing that hypothyroidism in the neonatal rat impairs testicular growth, germ cell maturation, formation of the lumen in seminiferous tubules, and other developmental events (Palmero et al. 1989, Francavilla et al. 1991, De França et al. 1995, Maran et al. 2001, Holsberger \& Cooke 2005).

The results of transmission electron microscopy demonstrated an atypical and disorganized Golgi apparatus, supporting alterations in protein processing. We also observed swollen mitochondria containing markedly dilated cristae in hypothyroid rat testis. These alterations in organelle morphology suggest a cellular response to the hypothyroid status.

We have recently demonstrated that both in vivo and in vitro treatment with $\mathrm{T}_{3}$ increased cytoskeletal vimentin phosphorylation in immature rat testis (Zamoner et al. 2005, 2007). In this context, hyperthyroidism could be associated with vimentin hyperphosphorylation and ERK pathway activation (Zamoner et al. 2007).

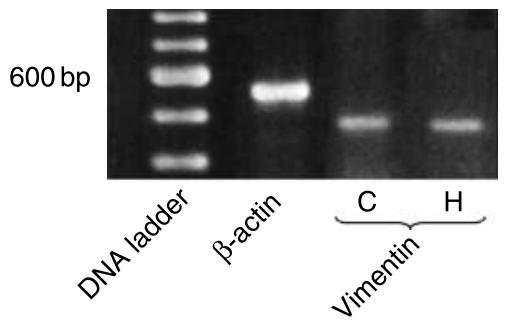

Figure 4 RT-PCR analysis of vimentin mRNA expression in control and hypothyroid rat testis. The larger band of DNA ladder correspond to $600 \mathrm{bp}$. C, control; $\mathrm{H}$, hypothyroid.
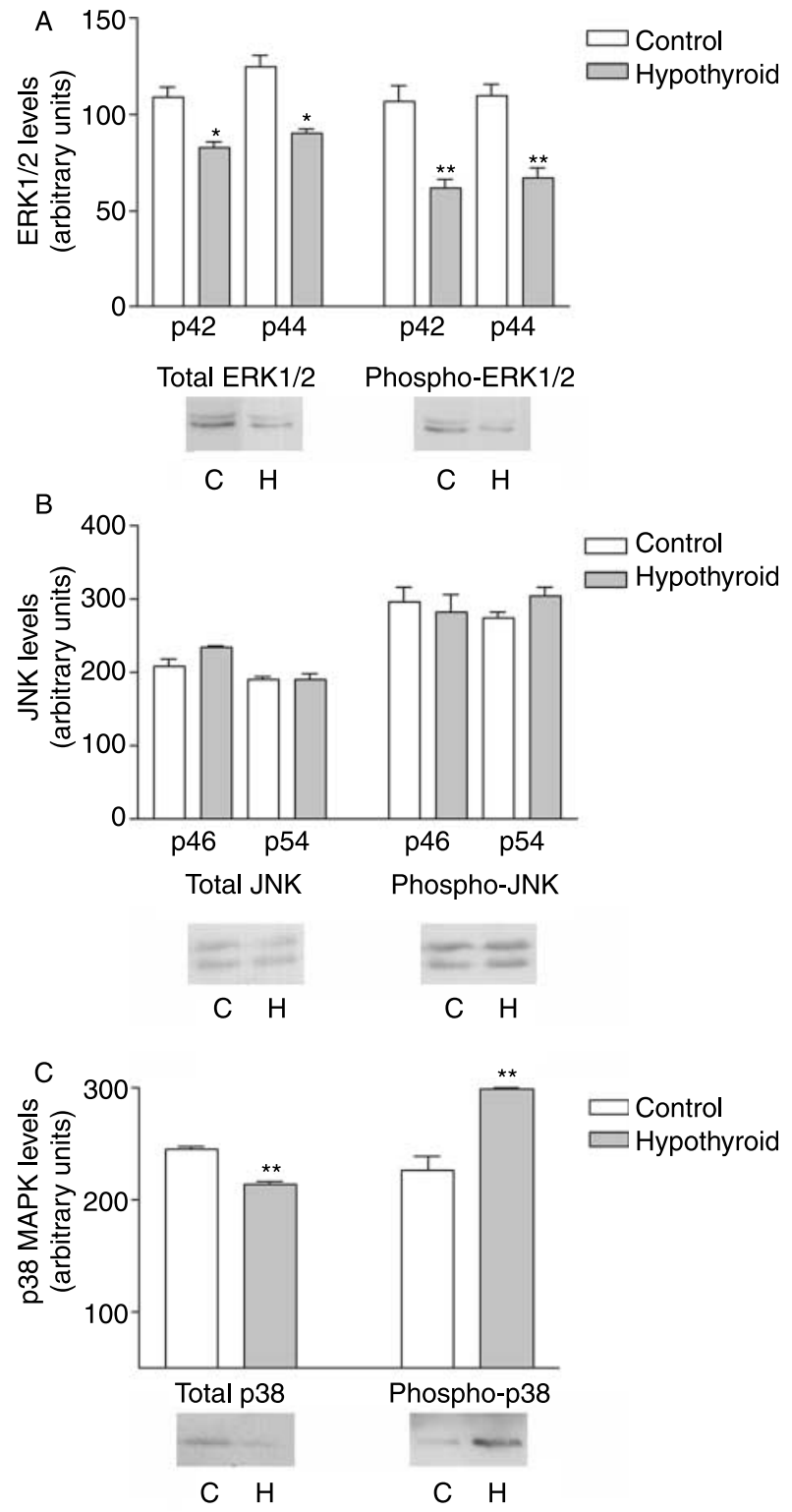

D Actin immunoblot

$$
\text { C } \mathrm{H}
$$

Figure 5 Effect of congenital hypothyroidism on MAPK pathways ERK1/2, JNK, and p38 kinase of immature rat testis. The immunocontent of total and phospho-ERK1/2, JNK, and p38 was measured in testis homogenate. Densitometry of $(A)$ total and phospho-ERK1/2, (B) total and phospho-JNK, (C) total and phospho-p38 kinase, (D) actin immunoblot showing equal protein loading. Representative immunoblots: $\mathrm{C}$, control; $\mathrm{H}$, hypothyroid. Scans from ten different animals from each group were quantified. Results are expressed as mean \pm S.E.M. Statistical analysis: oneway ANOVA followed by Tukey-Kramer multiple comparison test. ${ }^{\star} P<0.01,{ }^{\star \star} P<0.001$. 


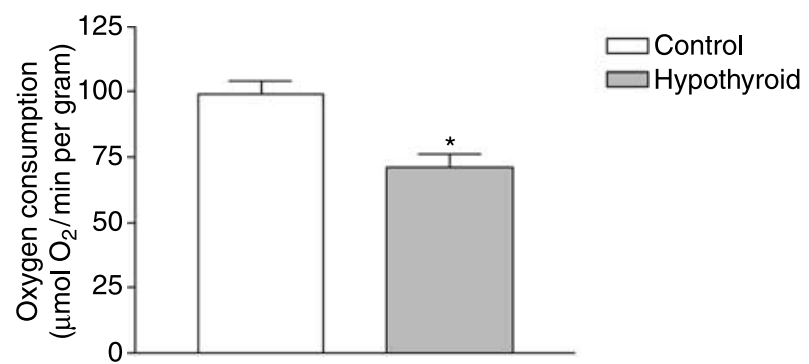

Figure 6 Effect of congenital hypothyroidism on oxygen consumption in immature rat testis. Data are reported as means \pm S.E.M. of ten animals from each group. Statistically significant differences from controls, as determined by Student's $t$-test, are indicated. ${ }^{*} P<0 \cdot 01$.

Interestingly, in hypothyroidism we also observed cytoskeletal-associated vimentin hyperphosphorylation; however, this effect could not be associated with ERK signaling, considering that we demonstrated decreased total and phospho-ERK levels. In addition, no changes were observed both in total and in phosphorylated JNK levels. On the other hand, the phospho-p38 MAPK levels were increased, despite decreased total p38 MAPK contents, suggesting that vimentin hyperphosphorylation might be, at least in part, related to alterations in p38 MAPK activity in hypothyroid rat testis. Our present findings concerning MAPK signaling pathways are in agreement with Franco et al. (2006) who have demonstrated that hypothyroidism was associated with high phospho-p38 MAPK and decreased phospho-ERK levels in liver. Our results emphasize that both hyperthyroidism (Zamoner et al. 2007) and hypothyroidism were associated with vimentin hyperphosphorylation, implying that alterations in the phosphorylation/dephosphorylation equilibrium of cytoskeletal proteins are a target for different physiological stimuli through different signaling mechanisms. The relevance of phosphorylation as a regulatory mechanism of the cytoskeletal dynamics lies on the fact

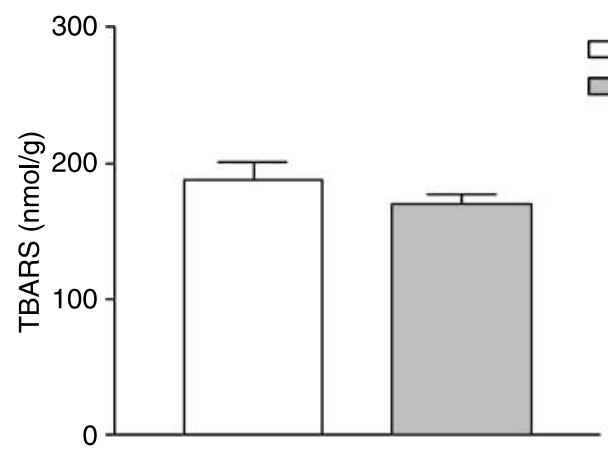

Figure 7 Effect of congenital hypothyroidism on lipid peroxidation in immature rat testis. Thiobarbituric acid-reactive substances (TBARS) measurement of lipid peroxidation. Data are reported as means \pm S.E.M. of 15 animals from each group as determined by Student's $t$-test. that IF proteins have multiple phosphate acceptor sites that could be sequentially and synergistically phosphorylated by several protein kinases leading to a multiplicity of cell responses (Roach 1991, Inagaki et al. 1997). Consequently, the sites of vimentin, which are phosphorylated in the hypothyroid status, could be different from the ones phosphorylated in the hyperthyroid status, which would explain the different polymerization/depolymerization equilibrium observed in these treatments. In hypothyroid rats, vimentin hyperphosphorylation was accompanied by increased vimentin immunoreactivity in the cytoskeletal fraction (vimentin in insoluble pool), despite the unaltered vimentin immunocontent in tissue homogenate that reflects the total content of the protein in the tissue (soluble and insoluble pool). These findings are in agreement with RT-PCR results showing no alterations in vimentin mRNA, indicating unaffected vimentin expression in hypothyroid rat testis. Nonetheless, the increased cytoskeletal-associated immunocontent of vimentin (insoluble) suggests that hypothyroidism might stimulate the ability of the phosphorylated form of this protein to polymerize/aggregate into cell testis. The modified vimentin phosphorylation/dephosphorylation equilibrium we are evidencing could support the altered structural organization observed in the hypothyroid testis cells, since it is known that the
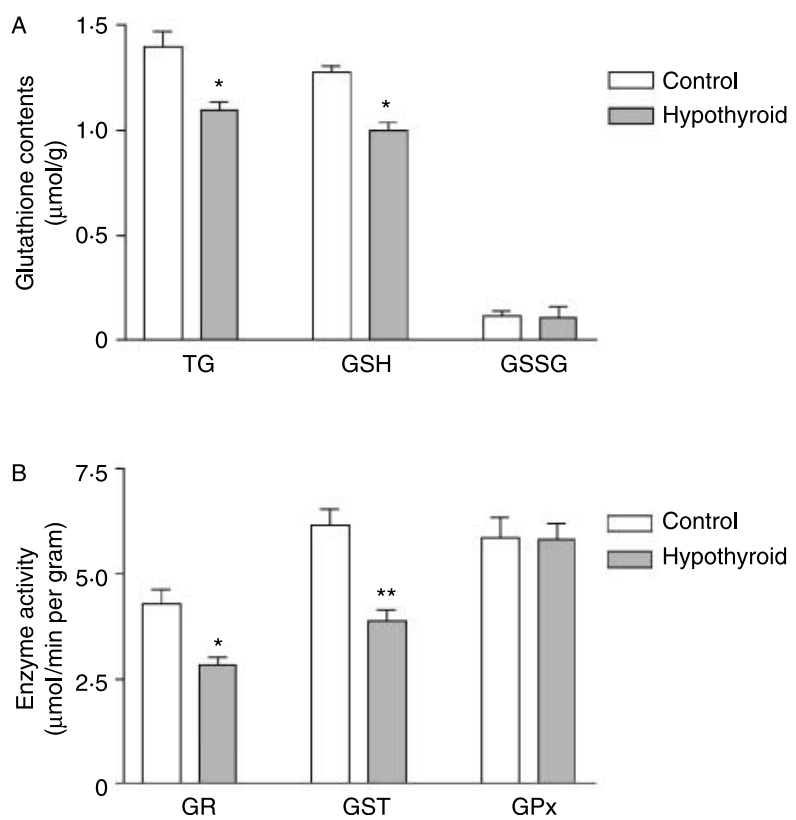

Figure 8 Effect of congenital hypothyroidism on glutathione levels and glutathione reductase (GR), glutathione peroxidase (GPx), and glutathione $S$-transferase (GST) activities in immature rat testis. (A) Total (TG), reduced (GSH), and oxidized (GSSG) glutathione levels. (B) Enzymatic activities of GR, GST, and GPx. Data are reported as means \pm S.E.M. of 12 animals from each group. Statistical analysis: one-way ANOVA followed by TukeyKramer multiple comparison test. ${ }^{\star} P<0.001,{ }^{\star \star} P<0.0001$. 

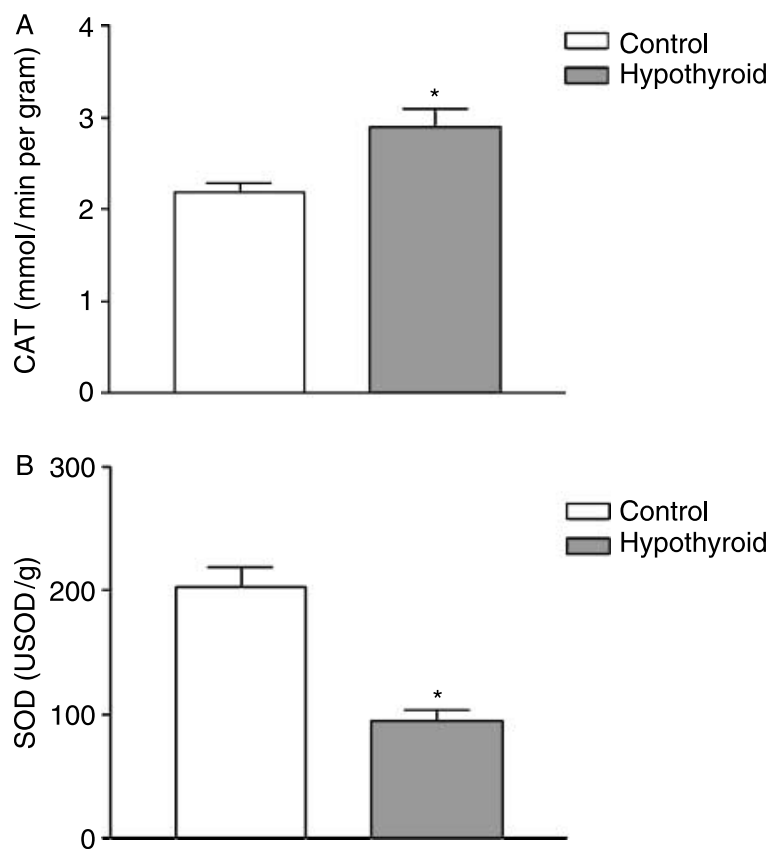

Figure 9 Effect of congenital hypothyroidism on catalase (CAT) and superoxide dismutase (SOD) activities in immature rat testis. (A) CAT and (B) SOD activities. Data are reported as means \pm S.E.M. of ten animals from each group. Statistically significant differences from controls, as determined by Student's $t$-test, are indicated. ${ }^{\star} P<0.01,{ }^{\star \star} P<0.0001$.

cytoarchitecture is dependent upon the dynamic properties of the cytoskeleton, which, in turn, are regulated by the phosphorylation/dephosphorylation equilibrium of their constituent proteins (Inagaki et al. 1996). Moreover, our findings concerning vimentin hyperphosphorylation indicate that the mechanisms underlying vimentin aggregation into the cytoskeletal fraction in hypothyroid rat testis does not involve increased vimentin expression, which is in contrast with the previously reported increased expression of phosphorylated vimentin in hyperthyroid rat testis (Zamoner et al. 2007).

In this context, an implication of the present findings is that the deleterious effects of hypothyroidism may be elicited, at least in part, by altering the physiological equilibrium of cytoskeletal protein polymerization/depolymerization leading to loss of Sertoli cell IF integrity. Moreover, the morphological alterations observed in Sertoli cell mitochondria and Golgi apparatus could be related to defective cytoskeletal dynamics implying in cell damage. The loss or disruption of vimentin filament structure and dynamics is a cause of germ cell apoptosis after testicular insult (Romeo et al. 1995), occurs in concert with the failure of spermatogenesis after hormonal withdrawal (Show et al. 2003), and may be one of the mechanisms of reproductive toxicity (He et al. 2007).
We have previously described vimentin hyperphosphorylation and overexpression associated with increased oxygen consumption and oxidative stress in hyperthyroid rat testis (Zamoner et al. 2007). On the contrary, the present results of decreased oxygen consumption in TH-deficient testis are supported by the classical TH modulation of the metabolism of several cell types (Norman \& Litwack 1997). Although lipid peroxidation, here estimated by TBARS levels, has been frequently used as an index of oxidative stress (Fernández et al. 1985, Venditti et al. 1997, Tapia et al. 1999, Zamoner et al. 2007), no alterations in this parameter were detected in hypothyroid rat testis.

The lower oxygen consumption in TH-deficient testis might be responsible for a lower ROS generation and therefore for the maintenance of lipoperoxidation levels. However, the induction of oxidative stress in the hypothyroid rat testis was detected in some enzymatic and non-enzymatic parameters of antioxidant defenses.

Total and reduced glutathione levels were decreased in TH-deficient rat testis, although GSSG was unaltered. These findings are consistent with the inhibition observed in GR and GST activities, since the interconversion GSH/GSSG/GSH is maintained by GR (Halliwell \& Gutteridge 1999, Dröge 2002, 2005, Venditti \& Di Meo 2006). However, the GPx activity was unaltered while the CAT activity was paradoxically increased and the SOD activity was also decreased in hypothyroid rat testis. In this context, the decline observed in TG and GSH levels, as well as the inhibition in SOD, GST, and GR activities highlight a relationship between hypothyroidism and oxidative stress in rat testis. GST uses GSH for its activity and depletion of reduced glutathione might be reflected in the lower GST activity. These enzymatic and non-enzymatic antioxidant defense dysregulation could be either the cause or the consequence of the oxidative stress due to poor ROS scavenging and, consequently, resulting in damage to testes cells. Irrespective of the levels of ROS generation, oxidative stress occurs if the antioxidants are lowered (Halliwell \& Gutteridge 1999).

In conclusion, the above results support the hypothesis that p38 MAPK activation, the cytoskeletal alterations, and the overall decreased antioxidant defenses leading to oxidative stress could represent some of the mechanisms underlying cell dysfunction induced by hypothyroidism in rat testis. Since the cytoskeleton participates in critical cell functions, including the physiological regulation of ROS release from mitochondria (Gourlay \& Ayscough 2005), cytoskeletal alterations induced by hypothyroidism might have important association with oxidative stress, as well as with morphological and biochemical changes in this tissue. 


\section{Acknowledgements}

This work was supported by Conselho Nacional de Desenvolvimento Científico e Tecnológico (CNPq), Fundação de Amparo à Pesquisa do Estado do Rio Grande do Sul (FAPERGS), and PROPESq-UFRGS. The authors are indebted to the Universidade Federal do Paraná (UFPR, Curitiba-PR, Brazil) for the electron microscope facilities. The authors declare that there is no conflict of interest that would prejudice the impartiality of this scientific work.

\section{References}

Aebi H 1984 Catalase in vitro. Methods in Enzymology 105 121-126. Beutler E 1975. Red Cell Metabolism: A Manual of Biochemical Methods. New York: Grune and Stratton.

Bird RP \& Draper AH 1984 Comparative studies on different methods of malondyhaldehyde determination. Methods in Enzymology $\mathbf{9 0}$ 105-110.

Brownlees J, Yates A, Bajaj NP, Davis D, Anderton BH, Leigh PN, Shaw CE \& Miller CC 2000 Phosphorylation of neurofilament heavy chain side-arms by stress activated protein kinase-1b/Jun N-terminal kinase-3. Journal of Cell Science 113 401-407.

Carlberg I \& Mannervik B 1985 Glutathione reductase from rat liver. Methods in Enzymology 113 484-490.

Chou YH, Opal P, Quinlan RA \& Goldman RD 1996 The relative roles of specific $\mathrm{N}$ - and C-terminal phosphorylation sites in the disassembly of intermediate filament in mitotic BHK-21 cells. Journal of Cell Science 109 817-826.

Choudhury S, Chainy GB \& Mishro MM 2003 Experimentally induced hypo- and hyper-thyroidism influence on the antioxidant defence system in adult rat testis. Andrologia 35 131-140.

Coulombe PA \& Wong P 2004 Cytoplasmic intermediate filaments revealed as dynamic and multipurpose scaffolds. Nature Cell Biology 6 699-706.

Dong H, Wade M, Williams A, Lee A, Douglas GR \& Yauk C 2005 Molecular insight into the effects of hypothyroidism on the developing cerebellum. Biochemical and Biophysical Research Communications 330 1182-1193.

Dröge W 2002 Free radicals in the physiological control of cell function. Physiological Reviews 82 47-96.

Dröge W 2005 Oxidative stress and ageing: is ageing a cysteine deficiency syndrome? Philosophical Transactions of the Royal Society of London. Series B 360 2355-2372.

Estabrook RW 1984 Mitochondrial respiratory control and the polarographic measurement of ADP-O2 ratios. Methods in Enzymology $1041-47$

Fernández V, Barrientos X, Kipreos K, Valenzuela A \& Videla LA 1985 Superoxide radical generation. NADPH oxidase activity and cytochrome P-450 content of rat liver microsomal fractions in a experimental hyperthyroid state: relation to lipid peroxidation. Endocrinology 117 496-501.

Flohé L \& Gunzler WA 1984 Assays of glutathione peroxidase. Methods in Enzymology 105 114-121.

De França LR, Hess RA, Cooke PS \& Russell LD 1995 Neonatal hypothyroidism causes delayed Sertoli cell maturation in rats treated with propylthiouracil: evidence that the Sertoli cell controls testis growth. Anatomical Record 242 57-69.

Francavilla S, Cordeschi G, Properzi G, Di Cicco L, Jannini EA \& Palmero S 1991 Effect of thyroid hormone on pre- and pos-natal development of the rat testis. Journal of Endocrinology 129 35-42.

Franco MC, Arciuch VGA, Peralta JG, Galli S, Levisman D, López LM, Romorini L, Poderoso JJ \& Carreras MC 2006 Hypothyroid phenotype is contributed by mitochondrial complex I inactivation due to translocated neuronal nitric oxide synthase. Journal of Biological Chemistry 281 4779-4786.

Franke FE, Pauls K, Rey R, Marks A, Bergmann M \& Steger K 2004 Differentiation markers of Sertoli cells and germ cells in fetal and early postnatal human testis. Anatomy and Embryology 209 169-177.

Funchal C, Vieira de Almeida LM, Oliveira Loureiro S, Vivian L, de Lima Pelaez P, Dall Bello Pessutto F, Rosa AM, Wajner M \& Pessoa-Pureur R 2003 In vitro phosphorylation of cytoskeletal proteins from cerebral cortex of rats. Brain Research Protocols 11 111-118.

Gaté L, Pau J, Ba GN, Tew KD \& Tapiero H 1999 Oxidative stress induced in pathologies: the role of antioxidants. Biomedicine and Pharmacotherapy 53 169-180.

Gourlay CW \& Ayscough KR 2005 The actin cytoskeleton: a key regulator of apoptosis and ageing? Nature 6 583-589.

Gravina FS, da Silveira CK, de Assis AM, Rieger DK, Guerini C, Müller AP, Farina M, Rotta LN \& Perry ML 2007 Experimental hypothyroidism inhibits delta-aminolevulinate dehydratase activity in neonatal rat blood and liver. Experimental Biology and Medicine 232 1021-1026.

Guma FCR, Mello TG, Mermelstein CS, Fortuna VA, Wofchuk ST, Gottfried C, Guaragna RM, Costa ML \& Borojevic R 2001 Intermediate filaments modulation in an in vitro model of the hepatic stellate cell activation or conversion into the lipocyte phenotype. Biochemistry and Cell Biology 79 409-417.

Habig WH, Pabst MJ \& Jakoby WB 1974 Glutathione $S$-tranferases: the first enzymatic step in mercapturic acid formation. Journal of Biological Chemistry 249 7130-7139.

Halliwell B \& Gutteridge JMC 1999. Free Radicals in Biology and Medicine, Oxford: Oxford University Press.

He D, Zhang D, Wei G, Lin T \& Li X 2007 Cytoskeleton vimentin disruption of mouse Sertoli cells injured by nitrogen mustard in vitro. Journal of Andrology 28 389-396.

Holsberger DR \& Cooke PS 2005 Understanding the role of thyroid hormone in Sertoli cell development: a mechanistic hypothesis. Cell and Tissue Research 322 133-140.

Holsberger DR, Kiesewetter SE \& Cooke PS 2005 Regulation of neonatal Sertoli cell development by thyroid hormone receptor $\alpha 1$. Biology of Reproduction 73 396-403.

Inada H, Togashi H, Nakamura Y, Kaibuchi K \& Inagaki M 1999 Balance between activities of Rho kinase and type 1 protein phosphatase modulates turnover of phosphorylation and dynamics of desmin/vimentin filaments. Journal of Biological Chemistry 274 34932-34939.

Inagaki M, Nishi Y, Nishizawa K, Matsuyama M \& Sato C 1987 Sitespecific phosphorylation induces disassembly of vimentin filaments in vitro. Nature 328 649-652.

Inagaki M, Matsuoka Y, Tsujimura K, Ando S, Tokui T, Takahashi T \& Inagaki N 1996 Dynamic property of intermediate filaments: regulation by phosphorylation. BioEssays 18 481-487.

Inagaki M, Inagaki N, Takahashi T \& Takai Y 1997 Phosphorylationdependent control of structures of intermediate filaments: a novel approach using site-and phosphorylation state-specific antibodies. Journal of Biochemistry 121 407-414.

Jannini EA, Ulisse S \& D'Armiento M 1995 Thyroid hormone and male gonadal function. Endocrine Reviews 16 443-459.

Jannini EA, Carosa E, Rucci N, Screponi E \& D’Armiento M 1999 Ontogeny and regulation of variant thyroid hormone receptor isoforms in developing rat testis. Journal of Endocrinological Investigation 22 843-848.

Laemmli UK 1970 Cleavage of structural proteins during the assembly of the head of the bacteriophage $\mathrm{T}_{4}$. Nature 277 680-685.

Lowry OH, Rosebrough NS, Farr AL \& Randall RJ 1951 Protein measurement with the Folin phenol reagent. Journal of Biological Chemistry 193 265-275.

Maran RR, Ravisankar B, Ravichandran K, Valli G, Arunakaran J \& Aruldhas MM 1999 Impact of neonatal onset hypothyroidism on Sertoli cell number, plasma and testicular interstitial fluid androgen binding protein concentration. Endocrine Research 25 307-322. 
Maran RR, Ravichandran K, Arunakaran J \& Aruldhas MM 2001 Impact of neonatal hypothyroidism on Leydig cell number, plasma, and testicular interstitial fluid sex steroids concentration. Endocrine Research 27 119-141.

Menet V, Gimenez y Ribotta M, Chauvet N, Drian M-J, Lannoy J, Colucci-Guyon E \& Privat A 2001 Inactivation of the glial fibrillary acidic protein gene, but not that of vimentin, improves neuronal survival and neurite growth by modifying adhesion molecule expression. Journal of Neuroscience 21 6147-6158.

Moro L, Marra E, Capuano F \& Greco M 2004 Thyroid hormone treatment of hypothyroid rats restores the regenerative capacity and the mitochondrial membrane permeability properties of the liver after partial hepatectomy. Endocrinology 145 5121-5128.

Norman AW \& Litwack G 1997 Thyroid hormones. In Hormones, pp 169-191. Eds AW Norman \& G Litwack. San Diego: Academic Press.

Ohkawa H, Ohishi N \& Yagi K 1979 Assay for lipid peroxides in animal tissues by thiobarbituric acid reaction. Analytical Biochemistry 95 351-358.

Palmero S, de Marchis M, Gallo G \& Fugassa E 1989 Thyroid hormone affects the development of Sertoli cell function in the rat. Journal of Endocrinology 123 105-111.

Potts RJ, Notarianni LJ \& Jefferies TM 2000 Seminal plasma reduces exogenous oxidative damage to human sperm, determined by the measurement of DNA strand breaks and lipid peroxidation. Mutation Research 447 249-256.

Rao JN, Liang JY, Chakraborti P \& Feng P 2003 Effect of thyroid hormone on the development and gene expression of hormone receptors in rat testes in vivo. Journal of Endocrinological Investigation 26 435-443.

Reynolds ES 1963 The use of lead citrate and high $\mathrm{pH}$ as an electron opaque stain in electron microscopy. Journal of Cell Biology 17 208-212.

Roach PJ 1991 Multisite and hierarchal protein phosphorylation. Journal of Biological Chemistry 266 14139-14142.

Romeo R, Castorina S \& Marcello MF 1995 Intermediate filaments of human Sertoli cells in germinal alterations. Italian Journal of Anatomy and Embryology 100 75-81.

Russel LD, Bartke A \& Goh JC 1989 Postnatal development of the Sertoli cell barrier, tubular lumen and the cytoskeleton of Sertoli and myoid cells in the rat, and their relationship to tubular fluid secretion and flow. American Journal of Anatomy 184 179-189.

Russell LD \& Peterson RN 1985 Sertoli cells junctions: morphological and functional correlates. International Review of Cytology 194 177-211.

Show MD, Anway MD, Folmer JS \& Zirkin BR 2003 Reduced intratesticular testosterone concentration alters the polymerization state of the Sertoli cell intermediate filament cytoskeleton by degradation of vimentin. Endocrinology 144 5530-5536.

Tanemura K, Kurohmaru M, Kuramoto K, Matsumoto M \& Hayashi Y 1994 Age-related changes in cytoskeletal components of the $\mathrm{BDF}_{1}$ mouse Sertoli cell. Tissue and Cell Research 26 447-455.
Tapia G, Cornejo P, Fernández V \& Videla LA 1999 Protein oxidation in thyroid hormone-induced liver oxidative stress: relation to lipid peroxidation. Toxicology Letters 106 209-214.

Tietze F 1969 Enzymic method for quantitative determination of nanogram amounts of total and oxidized glutathione: applications to mammalian blood and other tissues. Analytical Biochemistry 27 502-522.

Tindall DJ, Vitale R \& Means AR 1975 Androgen binding protein as a biochemical marker of formation of the blood-testis barrier. Endocrinology 97 636-648.

Venditti P, Balestrieri M, Di Meo S \& De Leo T 1997 Effect of thyroid state on lipid peroxidation, antioxidant defences and susceptibility to oxidative stress in rat tissues. Journal of Endocrinology 155 151-157.

Venditti P \& Di Meo S 2006 Thyroid hormone-induced oxidative stress. Cellular and Molecular Life Science 63 414-434.

Watson ML 1958 Staining of tissue sections for electron microscopy with heavy metals. Journal of Biophysical and Biochemical Cytology $\mathbf{4}$ $475-478$.

Wilhelm Filho D, Tribess TA \& Gáspari C 2001 Seasonal changes in antioxidant defenses in the digestive gland of the brown mussel (Perna perna). Aquaculture 203 149-158.

Zamoner A, Corbelini PF, Funchal C, Menegaz D, Silva FRMB \& Pessoa-Pureur R 2005 Involvement of calcium-dependent mechanisms on the action of $\mathrm{T}_{3}$ in the in vitro phosphorylation of vimentin oF immature rat testis. Life Sciences 77 3321-3335.

Zamoner A, Funchal C, Heimfarth L, Silva FR \& Pessoa-Pureur R 2006 Short-term effects of thyroid hormones on cytoskeletal proteins are mediated by GABAergic mechanisms in slices of cerebral cortex from young rats. Cellular and Molecular Neurobiology 26 209-224.

Zamoner A, Barreto KP, Wilhelm Filho D, Sell F, Woehl VM, Guma FC, Silva FRMB \& Pessoa-Pureur R 2007 Hyperthyroidism in the developing rat testis is associated with oxidative stress and hyperphosphorylated vimentin accumulation. Molecular and Cellular Endocrinology 267 116-126.

Zini A \& Schlegel PN 1996 Catalase mRNA expression in the male rat reproductive tract. Journal of Andrology 17 473-480.

Zini A \& Schlegel PN 1997a Identification and characterization of antioxidant enzyme mRNAs in the rat epididymis. International Journal of Andrology 20 86-91.

Zini A \& Schlegel PN $1997 b \mathrm{Cu} / \mathrm{Zn}$ superoxide dismutase, catalase and glutathione peroxidase mRNA expression in the rat testis after surgical cryptorchidism and efferent duct ligation. Journal of Urology 158 659-663.

Received in final form 5 December 2007

Accepted 2 January 2008

Made available online as an Accepted Preprint

2 January 2008 